\title{
Effect of Cadmium on Lactuca sativa Grown in Hydroponic Culture Enriched with Phosphate Fertilizer
}

\author{
Valérie S. Azzi1,2,3*, Ali Kanso1, Ahmad Kobeissi' ${ }^{1}$, Véronique Kazpard1, Bruno Lartiges², \\ Antoine El Samrani ${ }^{1}$ \\ ${ }^{1}$ Platform for Research and Analysis in Environmental Sciences, Doctoral School of Sciences and Technology \\ (EDST), Faculty of Science, Lebanese University, Hadat, Lebanon \\ ${ }^{2}$ Geosciences Environment Toulouse, University of Toulouse III, Toulouse, France \\ ${ }^{3}$ Lebanses Agriculture Research Institute, Fanar, Lebanon \\ Email: vvalerie.azzi@hotmail.com, antoineelsamrani@ul.edu.lb
}

Received 7 October 2015; accepted 28 November 2015; published 3 December 2015

Copyright (C) 2015 by authors and Scientific Research Publishing Inc.

This work is licensed under the Creative Commons Attribution International License (CC BY).

http://creativecommons.org/licenses/by/4.0/

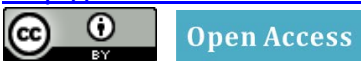

\begin{abstract}
Cadmium (Cd), one of the most toxic heavy metals added to soil after phosphate fertilizer treatment, was investigated. The effects of this metal on morphological and physiological changes of Lactuca sativa were studied in addition to its partitioning in different parts of the crop. In parallel, Lactuca sativa was allowed to grow under hydroponic conditions with modifications of the Hoagland nutrient solution. This solution was submitted to five Cd concentrations, 0, 0.093, 0.186, 0.279 and $0.372 \mathrm{mg} \mathrm{Cd} / \mathrm{L}$ and three $P$ concentrations, 0,299 and $1420 \mathrm{mg} P / \mathrm{L}$. The study showed a positive effect of phosphorus on root elongation, surface area while cadmium inhibited plant growth and sometimes the death of the plants. Cadmium was found to be accumulated in roots while zinc was preferably accumulated in the leaves and stems. The increase of performance of Lactuca sativa under hydroponic condition and Hoagland contaminated solution with cadmium was found to be better than the ones grown in $\mathrm{Cd}$ amended soil with or without phosphorus.
\end{abstract}

\section{Keywords}

Cadmium, Fertilizers, Hydroponic, Lactuca sativa, Phosphorus

\section{Introduction}

Cadmium (Cd) naturally occurs at trace levels in the environment but tends to accumulate abundantly in soils.

*Corresponding author.

How to cite this paper: Azzi, V.S., Kanso, A., Kobeissi, A., Kazpard, V., Lartiges, B. and El Samrani, A. (2015) Effect of Cadmium on Lactuca sativa Grown in Hydroponic Culture Enriched with Phosphate Fertilizer. Journal of Environmental Protection, 6, 1337-1346. http://dx.doi.org/10.4236/jep.2015.612116 
Accumulation is due to agricultural practices such as the application of phosphate fertilizers, use of wastewater for irrigation, and application of biosolids and composts from urban wastes [1]-[3]. It is considered as a potentially phytotoxic element due to its high toxicity and solubility in water [4]. Most general symptoms of Cd toxicity in plants are stunted growth, chlorosis, necrotic lesions, wilting and disturbances in mineral nutrition and carbohydrate metabolism. It strongly reduces biomass production and even conducts to integral plant death [4]-[6]. Cadmium has been shown to interfere with uptake, transport, and use of several nutrient elements and water by plants. It can suppress iron uptake by plants, induces P deficiency and reduces manganese transport to the plant [6]-[8]. It is readily absorbed by plant roots which are at the base of the food chain where it becomes very toxic to both plants and animals [9] [10].

Among cultivated plant species, Lactuca sativa (lettuce) is a worldwide important crop and one of the most consumed leafy vegetables in the human dietary [6] [11]. It is rich mainly in vitamins A and C and minerals such as iron and phosphorus [12]. In 2010, the world production of lettuce was approximately 24 million metric tons, with a cultivation area of 1 million hectares [13] [14]. This crop is known for its comparatively high accumulation of cadmium in leaves [9]. In this perspective, Lactuca sativa species has been designated for studying the impact of diets based on food crops cultivated on cadmium contaminated soils on human health [9]. It is chosen as a monitoring tool for the evaluation of the environmental contamination of $\mathrm{Ni}$ and Cd especially that EPA and the Organization for Economic Cooperation and Development have recommended this crop a key specie [14].

Nevertheless, since most of this crop is usually grown in greenhouses, with the application of special substrates and fertilization practices including water reuse, it is associated with the risk of increasing heavy metals concentration [6] [8]. Studies aiming to improve and understand cadmium toxicity in plant metabolism have been done on hydroponic cultures due to their easiness and suitability [15]. Hydroponic culture was used also to evaluate phytoextraction of cadmium and lead by sunflower, ricinus, alfalfa and mustard [16].

Hydroponics have several advantages including the possibility of using areas unsuitable for conventional farming, such as arid and degraded soils, independence of the crop to weather conditions leading to its cultivation all over the year [17], and reduction in the use of labor-intensive activities such as weeding and soil preparation. This technique allowed a reduction in the plant cycle (45 - 60 days), leading to an anticipated harvest; moreover, it enabled an active crop rotation, improved financial returns, and an efficient use of cultivation resources specially water and nutrients, while maintaining great environmental benefit.

Hydroponic systems weren't only associated to an increase in production yields, but also to a reduction in the overall production costs by enabling better control and standardization of the production process [13] [17]. In hydroponic crops, absorption is usually proportional to the concentration of nutrients in the solution near the roots influenced by the salinity, oxygenation, temperature and $\mathrm{pH}$ of the nutrient solution [13]. In soil, cadmium uptake is conditioned by its concentration in the soil and its bioavailability influenced by the presence of organic matter and clay, $\mathrm{pH}$, redox potential, temperature and concentrations of other elements [6].

In this context, lettuce has been selected due to several special features that aren't restricted to its high accumulation of cadmium in leaves, but also involving its capability of growing easily in hydroponic systems, which permit the control of the tissue metal concentration [18]. Studies emphasized on the impact of cadmium on the growth of lettuce plants, as well as on the absorption process of cadmium at the level of the roots, in addition to the distribution of cadmium through different organs [9].

To grow, plants, in soil or in hydroponic culture, need micronutrients and macronutrients. In the hydroponic culture, these nutrients were found in the Hoagland solution which was developed by D. R. Hoagland and D. I. Arnon in 1933 and was appropriate for the growth of large variety of plant species.

In order to understand the fundamental processes happening during the experiments, morphological and physiological characteristics, cadmium distribution in different parts of Lactuca sativa grown in hydroponic culture were investigated under five Cd concentrations, $0,0.093,0.186,0.279$ and $0.372 \mathrm{mg} \mathrm{Cd} / \mathrm{L}$ and three $\mathrm{P}$ concentrations, 0, 299 and $1420 \mathrm{mg} \mathrm{P} / \mathrm{L}$.

\section{Experimental Section}

\subsection{Hydroponic Support Cylinders}

Forty-five bins of $1150 \mathrm{~mL}$ volume each framed with black film were used for lettuces growth to prevent algal growth. 90 identical disks from rigid Styrofoam sheets were cut and measured to fit into the opening of the bins; 
45 disks were made from $1 \mathrm{~cm}$ thick sheets and 45 from $2 \mathrm{~cm}$. All disks were then perforated in two areas; one 2 $\mathrm{cm}$ hole in the middle of the disks and a $0.5 \mathrm{~cm}$ hole on a random area of the disk. Straws were pushed through this second hole and reach the bottom of the bin to aerate the system. Every $1 \mathrm{~cm}$ thick disk was then glued to a $2 \mathrm{~cm}$ thick disk, with an inert $5 \mathrm{~mm}$ net in between them, using regular white adhesive. The inert film acted as the support system for the lettuce plants, through which the roots of the plants pass to reach the nutrient solution underneath. Finally, the bins were randomly placed in a greenhouse of controlled temperature between $20^{\circ} \mathrm{C}$ and $23^{\circ} \mathrm{C}$ as the ideal temperature for lettuce development is $23^{\circ} \mathrm{C}$ [12], exposed to sunlight and artificially lit with numerous fluorescent lamps 24 hours a day, every day.

\subsection{Lactuca sativa Plants and Growth Conditions}

Forty five lettuce plants were grown on peat for 15 days; they were afterwards removed and rinsed by tap water to remove all remaining peat particles off the roots. The fifteen-day-old plantlets were then transferred to hydroponic conditions, with 45 plantlets gown in $1150 \mathrm{~mL}$ of aerated nutrient solution. The nutrient solution or Hoagland solution contained $6.0662 \times 10^{2} \mathrm{mg} / \mathrm{L} \mathrm{KNO}_{3}, 9.44 \mathrm{mg} / \mathrm{L} \mathrm{Ca}\left(\mathrm{NO}_{3}\right)_{2}, 4.92 \mathrm{mg} / \mathrm{L} \mathrm{MgSO}_{4}, 2.86 \times 10^{-3}$ $\mathrm{mg} / \mathrm{L} \mathrm{H}_{3} \mathrm{BO}_{3}, 1.18 \times 10^{-3} \mathrm{mg} / \mathrm{L} \mathrm{MnCl}_{2} \cdot 4 \mathrm{H}_{2} \mathrm{O}, 0.22 \times 10^{-3} \mathrm{mg} / \mathrm{L} \mathrm{ZnSO}{ }_{4} \cdot 7 \mathrm{H}_{2} \mathrm{O}, 0.08 \times 10^{-3} \mathrm{mg} / \mathrm{L} \mathrm{CuSO}{ }_{4} \cdot 5 \mathrm{H}_{2} \mathrm{O}$, $0.02 \times 10^{-3} \mathrm{mg} / \mathrm{L} \mathrm{H}_{2} \mathrm{MoO}_{4} \cdot \mathrm{H}_{2} \mathrm{O}, 2.61 \times 10^{3} \mathrm{mg} / \mathrm{L}$ EDTA, $1.9 \times 10^{3} \mathrm{mg} / \mathrm{L} \mathrm{KOH}$ and $2.49 \times 10^{3} \mathrm{mg} / \mathrm{L} \mathrm{FeSO}_{4} \cdot 7 \mathrm{H}_{2} \mathrm{O}$.

To study the effect of cadmium and phosphorus on the plant morphology, accumulation and transfer of cadmium into the lettuces, different concentrations of cadmium prepared from $\mathrm{CdCl}_{2} \cdot \mathrm{H}_{2} \mathrm{O}$ (99.99 \%; Sigma-Aldrich) and phosphorus prepared from simple superphosphate fertilizer $\left(18 \% \mathrm{P}_{2} \mathrm{O}_{5}\right)$ were added to the nutrient solution to complete the volume of bins to $1.15 \mathrm{~L}$ as showed in Table 1. Each treatment was triplicated. Metals identified in superphosphate fertilizer were very low; $\mathrm{Pb}, \mathrm{Cd}, \mathrm{Zn}$ and $\mathrm{Cu}$ were respectively $10 \pm 0.2 ; 5.1 \pm 0.8 ; 92.26 \pm 12$ and $6 \pm 0.5 \mathrm{mg} / \mathrm{Kg}$ of fertilizer which are very low contents considering the fertilizer added quantity.

The Hoagland solution without $\mathrm{P}$ and $\mathrm{Cd}$ were used as control samples. Nutrient solutions were changed twice a week over the course of the entire experiment.

At the eighth week, the lettuces were harvested. Leafs numbers were counted, plants height, roots length, shoots and roots fresh mass ( $\mathrm{FW}_{\mathrm{S}}$ and $\mathrm{FW}_{\mathrm{R}}$ respectively) and fresh leaves surface areas were measured. After these measurements, roots, stems and leaves were dried at $80^{\circ} \mathrm{C}$ for 48 hours in ventilated oven, and then dry mass of each part was determined ( $\mathrm{DW}_{\mathrm{R}}, \mathrm{DW}_{\mathrm{S}}$ and $\mathrm{DW}_{\mathrm{L}}$ for roots, stems and leaves dry weight respectively). Dry weight of the areal part (DWA $)$ was also measured.

Table 1. Hydropomic treatments.

\begin{tabular}{lcc}
\hline & \multicolumn{2}{c}{ Element concentrations } \\
\hline Preatments & $\mathrm{P}_{2} \mathrm{O}_{5}(\mathrm{mg} / \mathrm{L})$ & $\mathrm{Cd}(\mathrm{mg} / \mathrm{L})$ \\
\cline { 2 - 3 } & & $\mathrm{Cd} 0=0$ \\
P0Cd1 & $\mathrm{Pd} 0=0$ & $\mathrm{Cd} 1=0.093$ \\
P0Cd3 & & $\mathrm{Cd} 3=0.186$ \\
P0Cd4 & & $\mathrm{Cd} 4=0.372$ \\
P1Cd0 & $\mathrm{Cd} 0=0$ \\
P1Cd1 & $\mathrm{Cd} 1=0.093$ \\
P1Cd2 & $\mathrm{P} 1=686$ & $\mathrm{Cd} 2=0.186$ \\
P1Cd3 & & $\mathrm{Cd} 3=0.279$ \\
P1Cd4 & & $\mathrm{Cd} 4=0.372$ \\
P2Cd0 & & $\mathrm{Cd} 0=0$ \\
P2Cd1 & & $\mathrm{Cd} 1=0.093$ \\
P2Cd2 & & $\mathrm{Cd} 2=0.186$ \\
P2Cd3 & & $\mathrm{Cd} 3=0.279$ \\
P2Cd4 & $\mathrm{Cd} 2=3250$ & $\mathrm{Cd}=0.372$ \\
\hline
\end{tabular}


The dried samples were homogenized by grinding using a stainless steel blender. A sample mass between 50

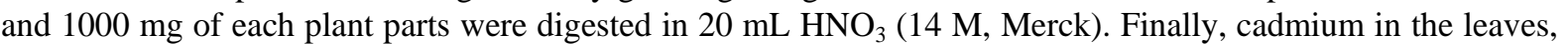
stems and roots of lettuces were analyzed using furnace atomic absorption spectrophotometer (AAS) (Rayleigh WFX-210 AA spectrophometer).

All the data reported represent an average of three replicates with standard deviation. XLSTAT software (Version 2014.5.03) was used to treat the data. One-way ANOVA was used to detect treatment effects, Duncan's test was used to determine significant differences between treatment means and Principal Component Analysis (PCA), Pearson ( $n-1)$ type was used to detect the correlations between the parameters. All statistical tests are used with an acceptable error margin of $5 \%$.

\section{Results and Discussion}

\subsection{Aerial Part of Lactuca sativa Grown under Cadmium Treatments}

In order to analyze the effects of cadmium on lettuce growth, plants length and number of leaves were determined during the 8 weeks of culture in the hydroponic systems. Plants submitted to high cadmium concentration or none $\mathrm{P}$ concentration were dead and some of its exhibited symptoms of necrosis (Figure 1).

Lettuces lengths increased by $45 \%$ between treatments with P and Cd (P0Cd0) and treatments with P and without Cd (P1Cd0, P2Cd0). This increase was only observed in treatments without Cd where the plants lengths decreased with increasing Cd concentrations (Table 2). Cadmium displayed a negative effect on lettuces growth where cadmium inside plant tissues can inhibit the photosynthesis by inhibiting chlorophyll and photosystem II together responsible of the photochemical efficiency of the plants [9] [11].

Leaves number and surface area decreased in all the treatments in a non-significant way with cadmium increase except in the treatments where $\mathrm{P}$ is at its highest concentration in the nutrient solution (P2) (Table 2).

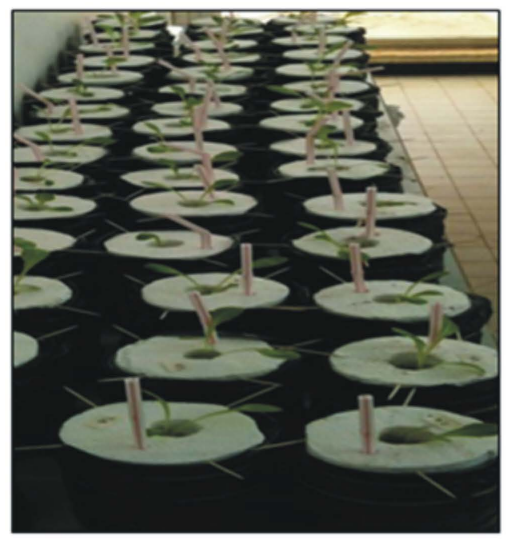

Day 8 of culture

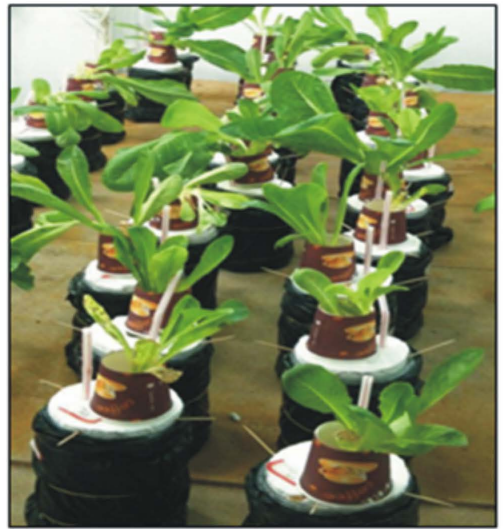

Day 42

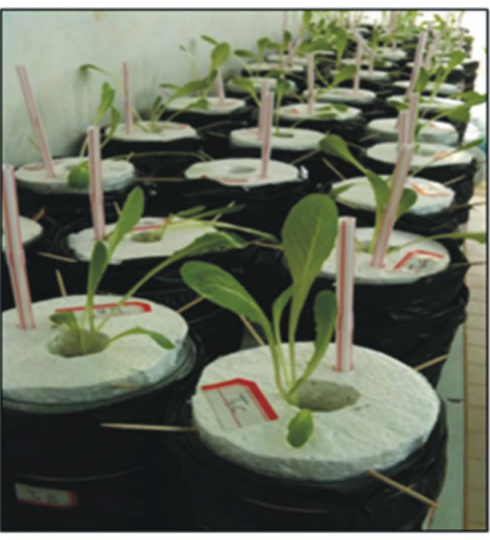

Day 17

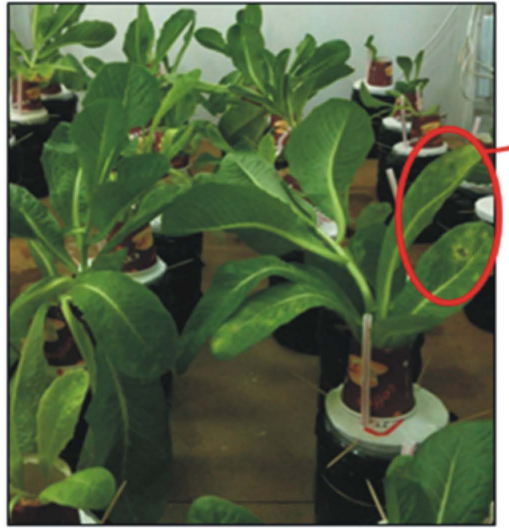

Day 51 of culture: Necrosis

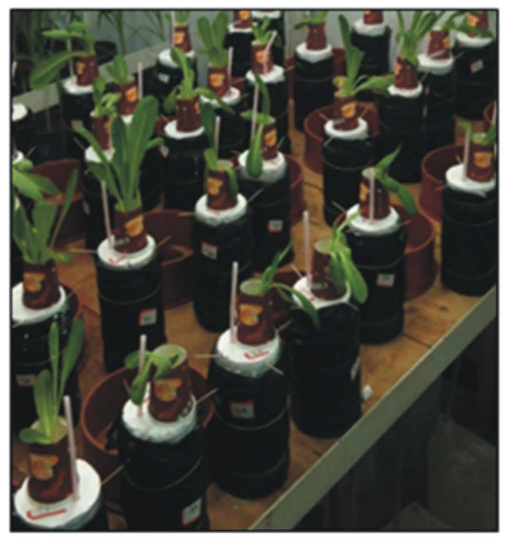

Day 29

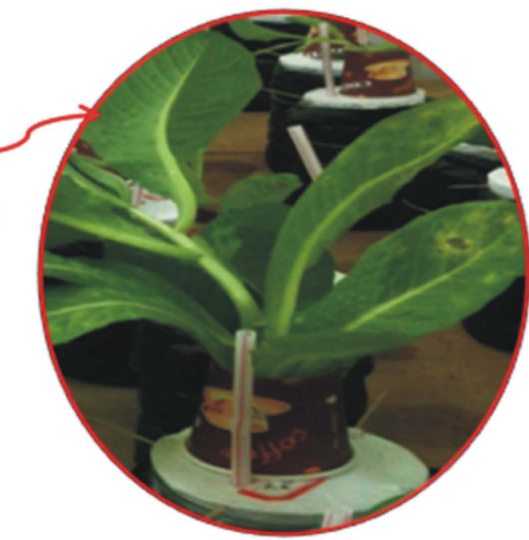

Figure 1. Evolution of the aerial part of Lactuca sativa. 
Table 2. Lettuces length, leaves numbers and surface area of lettuces under different treatments.

\begin{tabular}{|c|c|c|c|c|}
\hline \multirow{2}{*}{\multicolumn{2}{|c|}{ Treatments }} & \multicolumn{3}{|c|}{ Parameters } \\
\hline & & \multirow[t]{2}{*}{ Length $(\mathrm{cm})$} & \multirow[t]{2}{*}{ Leaves number } & \multirow[t]{2}{*}{ Surface area $\left(\mathrm{cm}^{2}\right)$} \\
\hline Phosphate & Cadmium & & & \\
\hline \multirow{5}{*}{ P0 } & Cd0 & $22 \pm 3.8^{\mathrm{ab}}$ & $9^{\mathrm{ab}}$ & $116 \pm 42.2^{\mathrm{a}}$ \\
\hline & $\mathrm{Cd} 1$ & $23 \pm 4.4^{\mathrm{ab}}$ & $9 \pm 0.9^{\mathrm{ab}}$ & $103 \pm 1.9^{\mathrm{a}}$ \\
\hline & $\mathrm{Cd} 2$ & $22 \pm 2.3^{\mathrm{ab}}$ & $10 \pm 0.5^{\mathrm{ab}}$ & $109 \pm 14.3^{\mathrm{a}}$ \\
\hline & $\mathrm{Cd} 3$ & $24 \pm 0.2^{\mathrm{abc}}$ & $9 \pm 0.5^{\mathrm{ab}}$ & $48 \pm 5^{\mathrm{a}}$ \\
\hline & $\mathrm{Cd} 4$ & $20 \pm 1.5^{\mathrm{a}}$ & $8^{\mathrm{a}}$ & $57 \pm 8.1^{\mathrm{a}}$ \\
\hline \multirow{5}{*}{ P1 } & $\mathrm{Cd} 0$ & $40 \pm 5.1^{\mathrm{e}}$ & $13 \pm 2.2^{b}$ & $532 \pm 99.4^{c}$ \\
\hline & Cd1 & $36 \pm 3.4^{\mathrm{de}}$ & $11 \pm 1^{\mathrm{ab}}$ & $412 \pm 98.2^{\mathrm{bc}}$ \\
\hline & $\mathrm{Cd} 2$ & $30 \pm 5.5^{\mathrm{bcd}}$ & $11 \pm 1^{\mathrm{ab}}$ & $244 \pm 113.7^{\mathrm{ab}}$ \\
\hline & $\mathrm{Cd} 3$ & $33 \pm 0.1^{\text {cde }}$ & $12 \pm 0.5^{\mathrm{ab}}$ & $204 \pm 41^{\mathrm{ab}}$ \\
\hline & $\mathrm{Cd} 4$ & $27 \pm 1.2^{\mathrm{abc}}$ & $9 \pm 0.5^{\mathrm{ab}}$ & $145 \pm 17.4^{\mathrm{a}}$ \\
\hline \multirow{5}{*}{ P2 } & Cd0 & $40 \pm 0.1^{\mathrm{e}}$ & $20 \pm 2.5^{c}$ & $986 \pm 131.7^{\mathrm{d}}$ \\
\hline & $\mathrm{Cd} 1$ & $30 \pm 3.1^{\mathrm{bcd}}$ & $20 \pm 3.5^{c}$ & $976 \pm 152.2^{\mathrm{d}}$ \\
\hline & $\mathrm{Cd} 2$ & $28 \pm 0.2^{\mathrm{abcd}}$ & $13 \pm 1.5^{\mathrm{ab}}$ & $303 \pm 2.5^{\mathrm{abc}}$ \\
\hline & $\mathrm{Cd} 3$ & $26 \pm 1.2^{\mathrm{abc}}$ & $12 \pm 1.5^{\mathrm{ab}}$ & $227 \pm 61.5^{\mathrm{ab}}$ \\
\hline & $\mathrm{Cd} 4$ & $28 \pm 1.1^{\mathrm{abcd}}$ & $12 \pm 1.5^{\mathrm{ab}}$ & $230 \pm 29.2^{\mathrm{ab}}$ \\
\hline
\end{tabular}

Means within columns followed by the same letters do not differ significantly according to Duncan’s multiple range test ( $\alpha=0.05$ ).

Increased leaves number and surface area were observed when P concentration was increased. For example, leaves number reached an augmentation of $45 \%$ between P1Cd1 and P2Cd1, the surface area increased by $78 \%$ and $88 \%$ between P0-P1and P0-P2 respectively and the lowest leaves number and surface area occurred in P0 due to the stress effect of the lettuces resulted from the absence of an important macro element (Table 2). At high cadmium level (Cd2 to Cd4), this metal had decreased lettuces productivity but at lower level (P0Cd0 and P0Cd1) where cadmium had stimulated productivity. For the leaves surface area, the phosphorus level played an important role. At low $\mathrm{P}$ concentration and in increasing Cd levels in the nutrient solution, leaf area decreased by $54 \%, 61 \%$ and $73 \%$ when comparing P1Cd2, P1Cd3 and P1Cd4 to P1Cd0 respectively. At higher P treatment (P2), a significant decrease by 73\% of surface area was observed between P2Cd0 or P2Cd1 and P2Cd2, P2Cd3 and P2Cd4. Therefore, the positive effect of phosphorus and the negative effect of Cd were both observed on the leaves number and the surface area in the treatments. The same negative effect of cadmium on the leaves surface area was shown on peas cultivated for 15 days with a 2.7-fold reduction in dry weight and surface area in comparison with peas cultivated without cadmium [5].

Fresh weights of stem $\left(\mathrm{FW}_{\mathrm{S}}\right)$ and leaves $\left(\mathrm{FW}_{\mathrm{L}}\right)$ were related to the number of leaves and the surface area (Table 3). Moreover, fresh weights of these aerial parts had a similar trend as leaves number and surface area in absence of phosphorus. They decreased in a non-significant way when increasing the cadmium level from 0 to $0.372 \mathrm{mg} / \mathrm{L}$ (Cd0 to $\mathrm{Cd} 4$ ) due to the stress in absence of phosphorus. Phosphorus enhanced $\mathrm{FW}_{\mathrm{S}}$ and $\mathrm{FW}_{\mathrm{L}}$ but these weights decreased in two ways when cadmium increased. $\mathrm{FW}_{\mathrm{S}}$ increased by $72 \%$ and $82 \%$ between P0-P1 and $\mathrm{P} 0-\mathrm{P} 2$ respectively and $\mathrm{FW}_{\mathrm{L}}$ increased by $82 \%$ and $92 \%$ in the same treatments without cadmium. A decrease by $30 \%$ and $18 \%$ was observed in $\mathrm{FW}_{\mathrm{S}}$ and $\mathrm{FW}_{\mathrm{L}}$ respectively when Cd level was $0.093 \mathrm{mg} / \mathrm{L}$ and reached its highest level (82\%) at Cd content equal to $0.372 \mathrm{mg} / \mathrm{L}$ (Figure 2).

Cadmium has been shown to interfere with the uptake and the transport of several elements since $\mathrm{Cd}^{2+}$ absorption occurs via the same transmembrane carriers used to uptake $\mathrm{Ca}^{2+}, \mathrm{Fe}^{2+}, \mathrm{Cu}^{2+}$ et $\mathrm{Mg}^{2+}$ leading to a disturbing of the growth of lettuces and decreasing in fresh weights [6] [7]. The weak decreases in $\mathrm{FW}_{\mathrm{S}}$ and $\mathrm{FW}_{\mathrm{L}}$ can be explained by the stimulatory effects of small amount of $\mathrm{Cd}$. The Cd stimulation on plant growth was observed in hydroponic experiments with rice, soybean and sorghum and is related to the disruption in the homeostasis of the plants [10]. 
Table 3. Matrix of Pearson correlation $(n-1)$ for physiological and morphological parameters of the lettuces aerial part.

\begin{tabular}{|c|c|c|c|c|c|c|c|}
\hline Variables & Leaves number & Surface area & $\mathrm{FW}_{\mathrm{L}}$ & $\mathrm{FW}_{\mathrm{S}}$ & $\mathrm{DW}_{\mathrm{s}}$ & $\mathrm{DW}_{\mathrm{L}}$ & $\mathrm{DW}_{\mathrm{AP}}$ \\
\hline Leaves number & 1 & & & & & & \\
\hline Surface area & 0.9502 & 1 & & & & & \\
\hline $\mathrm{FW}_{\mathrm{L}}$ & 0.8773 & 0.9561 & 1 & & & & \\
\hline $\mathrm{FW}_{\mathrm{S}}$ & 0.9063 & 0.9607 & 0.9490 & 1 & & & \\
\hline $\mathrm{DW}_{\mathrm{S}}$ & 0.9150 & 0.9268 & 0.8863 & 0.9252 & 1 & & \\
\hline $\mathrm{DW}_{\mathrm{L}}$ & 0.9147 & 0.9530 & 0.8822 & 0.9094 & 0.8840 & 1 & \\
\hline $\mathrm{DW}_{\mathrm{AP}}$ & 0.9184 & 0.9634 & 0.9334 & 0.9332 & 0.9046 & 0.9757 & 1 \\
\hline
\end{tabular}
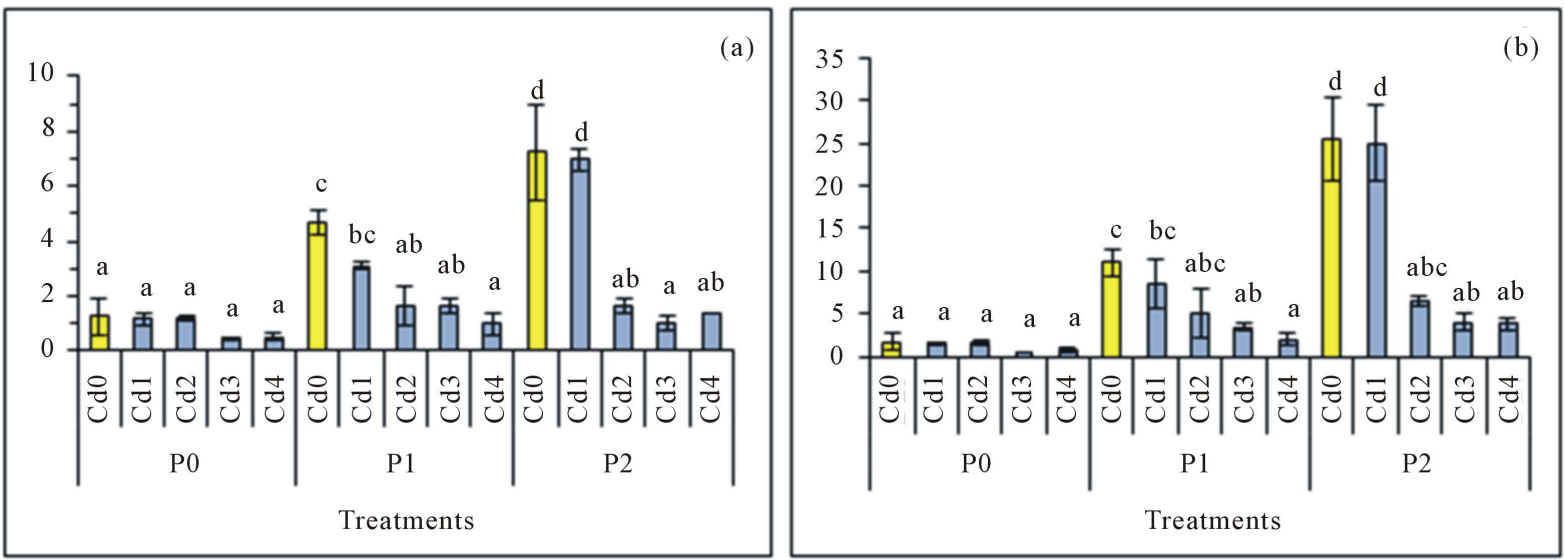

Figure 2. Fresh weight in (g) of (a) stems and (b) leaves of lettuces as function of P and Cd.

In addition to the cadmium inhibition effects on the $\mathrm{FW}_{\mathrm{S}}$ and $\mathrm{FW}_{\mathrm{L}}$, stems dry weight $\left(\mathrm{DW}_{\mathrm{S}}\right.$ ) and leaves dry weight $\left(\mathrm{DW}_{\mathrm{L}}\right)$ exposed to medium concentrations of $\mathrm{Cd}$ had a similar behavior as $\mathrm{FW}_{\mathrm{S}}$ and $\mathrm{FW}_{\mathrm{L}}$ due to the interference of Cd with the nutrients. In fact, when phosphorus was increased from P0 to P1 to P2, DW $\mathrm{S}_{\mathrm{S}}$ and $\mathrm{DW}_{\mathrm{L}}$ increased together but they decreased in a non-significant way when $\mathrm{Cd}$ was added. The increase of dry weights was less than the fresh weight for the stems and leaves. It reached $50 \%$ and $67 \%$ for DWs, $73 \%$ and $81 \%$ for $\mathrm{DW}_{\mathrm{L}}$ in P1Cd0 and P2Cd0 compared to P0Cd0 respectively (Table 4). However, in a previous study, DW $\mathrm{L}$ decrease with cadmium concentration was also observed in Brassica juncea in hydroponic culture when cadmium was applied between 9 and $30 \mathrm{mg} / \mathrm{L}$ [10].

The dry weight of the aerial part of lettuces $\mathrm{DW}_{\mathrm{A} . \mathrm{P}}$ was positively correlated to fresh and dry weight of stems and leaves (Table 3). $\mathrm{DW}_{\mathrm{A} . \mathrm{P}}$ increased by $58 \%$ and 52\% when P level was 686 and $3250 \mathrm{mg} / \mathrm{L}$ compared to the treatment in absence of phosphorus and cadmium. A decrease by $48 \%$ and $65 \%$ occurs between the two couples $\mathrm{P} 1 \mathrm{Cd} / \mathrm{P} 1 \mathrm{Cd} 2$ and P2Cd0/P2Cd2 respectively. However, for cadmium concentrations beyond $0.186 \mathrm{mg} / \mathrm{L}$ and in presence of phosphorus, $\mathrm{DW}_{\mathrm{AP}}$ values were stable while no effect of $\mathrm{P}$ or $\mathrm{Cd}$ was identified, revealing the formation of Cd-P complex that inhibited cadmium effect.

\subsection{Root Part of Lactuca sativa Grown under Cadmium Treatments}

Root length of lettuces in treatments P0 didn't show any changes when cadmium was added. The presence of $100 \mu \mathrm{M}$ Cd didn't affect root length of lettuces after 7 days of culture in Hoagland's medium enriched with $\mathrm{Cd}\left(\mathrm{NO}_{3}\right)_{2}$ [11]. When phosphorus was added at $686 \mathrm{mg} / \mathrm{L}$ level, root length was inhibited only when cadmium was at its highest level $(0.372 \mathrm{mg} / \mathrm{L})$ and this behavior was not observed when P2 was applied enhancing the hypothesis of Cd-P complex formation in roots that inhibits cadmium absorption [4] (Table 5). Although in non-significant way, root length was increased when $\mathrm{P}$ was added as it is a limiting factor for plant and root growth. The reduction in root growth is due to low P-induced that inhibits cell division in the root meristem and changes of the root system architecture [19]. 
Table 4. Dry weights of the stems and leaves and fresh weight of the aerial parts of the lettuces in the different treatments.

\begin{tabular}{|c|c|c|c|c|}
\hline \multirow{2}{*}{\multicolumn{2}{|c|}{ Treatments }} & \multicolumn{3}{|c|}{ Parameters } \\
\hline & & \multirow[t]{2}{*}{$\mathrm{DW}_{\mathrm{S}}(\mathrm{g})$} & \multirow[t]{2}{*}{$\mathrm{DW}_{\mathrm{L}}(\mathrm{g})$} & \multirow[t]{2}{*}{$\mathrm{DW}_{\mathrm{AP}}(\mathrm{g})$} \\
\hline Phosphate & Cadmium & & & \\
\hline \multirow{5}{*}{ P0 } & Cd0 & $0.142 \pm 0.08^{\mathrm{a}}$ & $0.51 \pm 0.07^{\mathrm{a}}$ & $0.647 \pm 0.16^{\mathrm{ab}}$ \\
\hline & $\mathrm{Cd} 1$ & $0.164 \pm 0.05^{\mathrm{ab}}$ & $0.46 \pm 0.07^{\mathrm{a}}$ & $0.509 \pm 0.1^{\mathrm{ab}}$ \\
\hline & $\mathrm{Cd} 2$ & $0.075 \pm 0.003^{\mathrm{a}}$ & $0.53 \pm 0.1^{\mathrm{a}}$ & $0.695 \pm 0.15^{\mathrm{ab}}$ \\
\hline & $\mathrm{Cd} 3$ & $0.063 \pm 0.01^{\mathrm{a}}$ & $0.43 \pm 0.03^{\mathrm{a}}$ & $0.374 \pm 0.14^{\mathrm{a}}$ \\
\hline & $\mathrm{Cd} 4$ & $0.027 \pm 0.01^{\mathrm{a}}$ & $0.42 \pm 0.03^{\mathrm{a}}$ & $0.419 \pm 0.1^{\mathrm{a}}$ \\
\hline \multirow{5}{*}{$\mathrm{P} 1$} & $\mathrm{Cd} 0$ & $0.286 \pm 0.01^{\mathrm{b}}$ & $1.39 \pm 0.13^{\mathrm{b}}$ & $1.528 \pm 0.24^{c}$ \\
\hline & $\mathrm{Cd} 1$ & $0.137 \pm 0.05^{\mathrm{a}}$ & $1 \pm 0.04^{\mathrm{ab}}$ & $1.135 \pm 0.09^{\mathrm{bc}}$ \\
\hline & $\mathrm{Cd} 2$ & $0.096 \pm 0.03^{\mathrm{a}}$ & $0.68 \pm 0.03^{\mathrm{a}}$ & $0.789 \pm 0.05^{\mathrm{ab}}$ \\
\hline & $\mathrm{Cd} 3$ & $0.092 \pm 0.01^{\mathrm{a}}$ & $0.64 \pm 0.04^{\mathrm{a}}$ & $0.743 \pm 0.03^{\mathrm{ab}}$ \\
\hline & $\mathrm{Cd} 4$ & $0.078 \pm 0.03^{\mathrm{a}}$ & $0.55 \pm 0.08^{\mathrm{a}}$ & $0.648 \pm 0.12^{\mathrm{ab}}$ \\
\hline \multirow{5}{*}{ P2 } & $\mathrm{Cd} 0$ & $0.426 \pm 0.12^{\mathrm{c}}$ & $2.77 \pm 0.2^{\mathrm{c}}$ & $3.192 \pm 0.08^{\mathrm{d}}$ \\
\hline & $\mathrm{Cd} 1$ & $0.469 \pm 0.08^{c}$ & $2.67 \pm 0.73^{\mathrm{c}}$ & $3.161 \pm 0.66^{\mathrm{d}}$ \\
\hline & $\mathrm{Cd} 2$ & $0.172 \pm 0.01^{\mathrm{ab}}$ & $0.81 \pm 0.14^{\mathrm{ab}}$ & $1.112 \pm 0.07^{\mathrm{bc}}$ \\
\hline & $\mathrm{Cd} 3$ & $0.104 \pm 0.03^{\mathrm{a}}$ & $0.73 \pm 0.09^{\mathrm{ab}}$ & $0.764 \pm 0.05^{\mathrm{ab}}$ \\
\hline & $\mathrm{Cd} 4$ & $0.096 \pm 0.02^{\mathrm{a}}$ & $0.7 \pm 0.2^{\mathrm{a}}$ & $0.793 \pm 0.21^{\mathrm{ab}}$ \\
\hline
\end{tabular}

Means within columns followed by the same letters do not differ significantly according to Duncan’s multiple range test $(\alpha=0.05)$.

Table 5. Root length, fresh and dry weights of roots of the lettuces.

\begin{tabular}{|c|c|c|c|c|}
\hline \multirow{2}{*}{\multicolumn{2}{|c|}{ Treatments }} & \multicolumn{3}{|c|}{ Parameters } \\
\hline & & \multirow[t]{2}{*}{ Root length (cm) } & \multirow[t]{2}{*}{$\mathrm{FW}_{\mathrm{R}}(\mathrm{g})$} & \multirow[t]{2}{*}{$\mathrm{DW}_{\mathrm{R}}(\mathrm{g})$} \\
\hline Phosphate & Cadmium & & & \\
\hline \multirow{5}{*}{ P0 } & Cd0 & $16 \pm 4.1^{\mathrm{abcd}}$ & $1.34 \pm 0.5^{\mathrm{abcd}}$ & $0.156 \pm 0.0045^{b c}$ \\
\hline & $\mathrm{Cd} 1$ & $17 \pm 0.4^{\text {abcd }}$ & $1.3 \pm 0.3^{\mathrm{abc}}$ & $0.157 \pm 0.0029^{b c}$ \\
\hline & $\mathrm{Cd} 2$ & $14 \pm 1.2^{\mathrm{abcd}}$ & $1.2 \pm 0.4^{\mathrm{abc}}$ & $0.159 \pm 0.0087^{\mathrm{bc}}$ \\
\hline & $\mathrm{Cd} 3$ & $14 \pm 2.5^{\mathrm{abc}}$ & $0.38 \pm 0.08^{\mathrm{a}}$ & $0.048 \pm 0.0079^{\mathrm{a}}$ \\
\hline & $\mathrm{Cd} 4$ & $13 \pm 0.6^{\mathrm{ab}}$ & $0.63 \pm 0.2^{\mathrm{a}}$ & $0.052 \pm 0.0136^{\mathrm{a}}$ \\
\hline \multirow{5}{*}{ P1 } & Cd0 & $18 \pm 0.9^{\mathrm{cd}}$ & $2.72 \pm 0.3^{\mathrm{d}}$ & $0.136 \pm 0.0165^{\mathrm{ab}}$ \\
\hline & Cd1 & $18 \pm 0.8^{\mathrm{cd}}$ & $2.56 \pm 0.5^{\mathrm{cd}}$ & $0.134 \pm 0.0187^{\mathrm{ab}}$ \\
\hline & $\mathrm{Cd} 2$ & $16 \pm 1.4^{\mathrm{cbcd}}$ & $1.54 \pm 0.1^{\mathrm{abcd}}$ & $0.088 \pm 0.0048^{\mathrm{ab}}$ \\
\hline & $\mathrm{Cd} 3$ & $15 \pm 0.4^{\mathrm{abcd}}$ & $1.23 \pm 0.1^{\mathrm{abc}}$ & $0.081 \pm 0.0014^{\mathrm{ab}}$ \\
\hline & $\mathrm{Cd} 4$ & $13 \pm 2.5^{\mathrm{a}}$ & $1.04 \pm 0.3^{\mathrm{ab}}$ & $0.063 \pm 0.0188^{\mathrm{ab}}$ \\
\hline \multirow{5}{*}{$\mathrm{P} 2$} & Cd0 & $18 \pm 0.6^{\mathrm{bcd}}$ & $5.14 \pm 1^{\mathrm{e}}$ & $0.246 \pm 0.0656^{\mathrm{cd}}$ \\
\hline & $\mathrm{Cd} 1$ & $19 \pm 0.6^{\mathrm{d}}$ & $5.3 \pm 0.7^{\mathrm{e}}$ & $0.303 \pm 0.0784^{\mathrm{d}}$ \\
\hline & $\mathrm{Cd} 2$ & $17 \pm 0.7^{\mathrm{abcd}}$ & $2.25 \pm 0.6^{\mathrm{bcd}}$ & $0.1 \pm 0.0055^{\mathrm{ab}}$ \\
\hline & $\mathrm{Cd} 3$ & $17 \pm 1^{\mathrm{abcd}}$ & $1.71 \pm 0.2^{\mathrm{abcd}}$ & $0.107 \pm 0.009^{\mathrm{ab}}$ \\
\hline & $\mathrm{Cd} 4$ & $17 \pm 0.2^{\mathrm{abcd}}$ & $1.29 \pm 0.26^{\mathrm{abc}}$ & $0.097 \pm 0.0297^{\mathrm{ab}}$ \\
\hline
\end{tabular}

Means within columns followed by the same letters do not differ significantly according to Duncan’s multiple range test $(\alpha=0.05)$. 
Unlike the root length, the fresh weight of roots $\left(\mathrm{FW}_{\mathrm{R}}\right)$ decreased when phosphorus was absent and when cadmium was increased in the nutrient solution. $\mathrm{FW}_{\mathrm{R}}$ increased when phosphorus increased. It increased by $67 \%$ and $80 \%$ in $\mathrm{P} 1$ and $\mathrm{P} 2$ respectively compared to P0. Under the same phosphorus concentration, $\mathrm{FW}_{\mathrm{R}}$ decreased by an average of $64 \%$ in P1Cd4 and P2Cd2 compared to P1Cd0 and P2Cd0 respectively. At high P level (P2), $\mathrm{FW}_{\mathrm{R}}$ wasn't affected by Cd when its concentration was above $0.186 \mathrm{mg} / \mathrm{L}$ (Table 5).

The same behavior was observed for the dry weight of the roots $\left(\mathrm{DW}_{\mathrm{R}}\right)$ with an exception of a $70 \%$ reduction in $\mathrm{DW}_{\mathrm{R}}$ when lettuces were grown in treatment without phosphorus and under high concentration levels of cadmium (Cd3 and Cd4). Root length, $\mathrm{FW}_{\mathrm{R}}$ and $\mathrm{DW}_{\mathrm{R}}$ were found positively correlated but in moderate way (0.4 0.6). Thus it can be due to an increase of the density of the lateral roots and reduction of the primary root length in response to low P availability and cadmium presence. Previous studies reported that low P level induce the increase of lateral root number and density over primary root growth [19] [20].

\subsection{Cadmium Transfer to Lactuca sativa}

Most of the cadmium was accumulated in lettuces roots when the concentration of this heavy metal was greater than $0.186 \mathrm{mg} / \mathrm{L}$ and in absence of phosphorus. When phosphorus level and cadmium was increased together in the nutrient solution till $299 \mathrm{mg} \mathrm{P} / \mathrm{L}$ (P1) and $0.093 \mathrm{mg} \mathrm{Cd} / \mathrm{L}$, cadmium level found in the roots was increased and the one in the aerial part was diminished (Figure 3). Cadmium in aerial part and roots was increased in the treatment P2Cd0 compared to P0Cd0.

In fact, phosphorus had a role in developing the root system. Hence it is not surprising to find that cadmium absorption is more important in presence of phosphorus than in its absence, but the absorption varies with the cadmium availability to plants. The quantity transferred to the stems and leaves was almost the same in all the treatments. Accordingly, the partition of the cadmium in different lettuces parts could be a useful strategy to avoid toxicity in aerial parts.

Iron found in lettuces roots was more abundant than in aerial parts. Its absorption decreased when phosphorus was added no matter the cadmium concentration present in the nutrient solution. However, Zinc had a different behavior. Zn was accumulated in the leaves then in roots and the smallest amount of zinc was found in the stems (Table 6).

It is known in the literature than cadmium absorption is influenced by the presence of zinc since they belong to the same group in the periodic table and have a similar nuclear structure and ionic radius [21] [22]. In this study, $\mathrm{Zn}$ was found inversely proportional to $\mathrm{Cd}$ and in the tissues where cadmium was present in large quantities, $\mathrm{Zn}$ was very low and vice-versa, thus a competition between those elements [21] [23] [24]. In fact, an antagonistic interaction for $\mathrm{Cd}$ and $\mathrm{Zn}$ uptake and translocations by plants was demonstrated by several authors [25] [26].

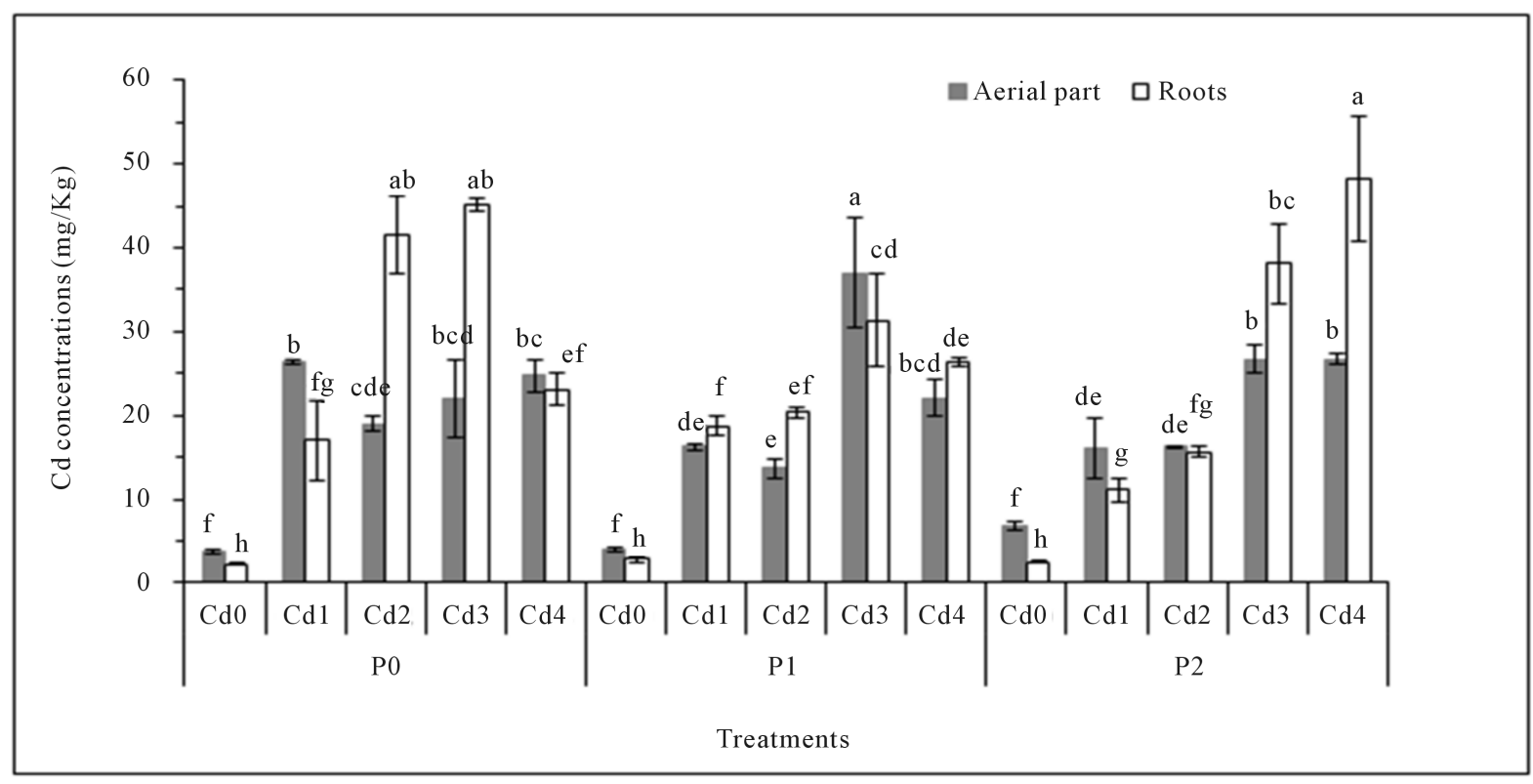

Figure 3. Cadmium levels in aerial and root parts of lettuces in all treatments. 
Table 6. Iron and zinc concentrations in the different parts of the lettuces.

\begin{tabular}{cccccc}
\hline & \multicolumn{5}{c}{ Elements } \\
\cline { 2 - 6 } Phosphate levels & \multicolumn{2}{c}{ Fe (mg/g) } & Zn (mg/g) & Roots \\
\cline { 2 - 6 } & Aerial parts & Roots & Leaves & Stems & $38 \pm 1.5$ \\
\cline { 2 - 6 } P0 & $299.8 \pm 52$ & $3364 \pm 231$ & $592 \pm 39$ & $23 \pm 9$ & $53 \pm 5.6$ \\
P1 & $70.4 \pm 7$ & $1606 \pm 185$ & $478 \pm 42$ & $16 \pm 2$ & $66 \pm 4$ \\
\hline
\end{tabular}

\section{Conclusions}

Phosphate fertilizer was found to increase leaves number, surface area, root elongation and fresh and dry weight of stems and leaves. Phosphorus had an important role in developing the root system. However, cadmium induced opposite effects on the plants when present in the nutrient solution; it conducted the death and the necrosis of some lettuces plants. On the other hand, cadmium had decreased fresh and dry weights of stems and leaves, root length and fresh and dry weight of roots. In highly cadmium contaminated nutrient solution, roots of Lactuca sativa absorbed the cadmium that was transferred to the aerial lettuces parts. Absorption of Cd was influenced by the presence of $\mathrm{Zn}$ in the nutrient solution that was accumulated in the stems and leaves of the plants while $\mathrm{Fe}$ and $\mathrm{Cd}$ were accumulated in the roots. With increasing Cd concentration in the Hoagland solution and at high $\mathrm{P}$ level, the absorption and transfer of cadmium increased for both in the roots and the aerial parts.

Despite the easiness and rapidity of crop growth in hydroponic culture, this system may become a potential source of bioavailable cadmium that is absorbed by lettuces and transferred to roots and aerial parts conducting at least to deep morphological changes. The sufficient presence of phosphorus in nutrient media may inhibit cadmium or iron absorption by the plants. Therefore, a particular attention must be done when Cd enriched phosphate fertilizers are used in hydroponic culture cycles.

\section{Acknowledgements}

This research has been financed by research grant programs of the Lebanese University and the Lebanese Agriculture Research Institute. The authors would like to thank an anonymous reviewer for helpful comments that improved the clarity of this paper.

\section{References}

[1] Belon, E., Boisson, M., Deportes, I.Z., Eglin, T.K., Feix, I., Bispo, A.O., Galsomies, I., Leblond, S. and Guellier, C.R. (2012) An Inventory of Trace Elements Inputs to French Agricultural Soils. Science of the Total Environment, 439, 8795. http://dx.doi.org/10.1016/j.scitotenv.2012.09.011

[2] Thakur, S.K., Tomar, N.K. and Pandeya, S.B. (2006) Influence of Phosphate on Cadmium Sorption by Calcium Carbonate. Geoderma, 130, 240-249. http://dx.doi.org/10.1016/j.geoderma.2005.01.026

[3] Kirkham M.B. (2006) Cadmium in Plants on Polluted Soils: Effects of Soil Factors, Hyperaccumulation, and Amendments. Geoderma, 137, 19-32. http://dx.doi.org/10.1016/j.geoderma.2006.08.024

[4] Dheri, G.S., Brar, M.S. and Malhi, S.S. (2007) Influence of Phosphorus Application on Growth and Cadmium Uptake of Spinach in Two Cadmium-Contaminated Soils. Journal of Plant Nutrition Soil Science, 170, 495-499. http://dx.doi.org/10.1002/jpln.200625051

[5] Romero-Puertas, M.C., Rodríguez-Serrano, M., Corpas, F.J., Gómez, M., Del Río, L.A. and Sandalio, L.M. (2004) Cadmium-Induced Subcellular Accumulation of $\mathrm{O}_{2}^{-}$and $\mathrm{H}_{2} \mathrm{O}_{2}$ in Pea Leaves. Plant, Cell \& Environment, 27, 11221134. http://dx.doi.org/10.1111/j.1365-3040.2004.01217.x

[6] Dias, M.C, Monteiro, C., Moutinho-Pereira, J., Correia, C., Gonçalves, B. and Santos, C. (2012) Cadmium Toxicity Affects Photosynthesis and Plant Growth at Different Levels. Acta Physiologiae Plantarum, 35, 1281-1289.

[7] Das, P., Samantaray, S. and Rout, G.R. (1997) Studies on Cadmium Toxicity in Plants: A Review. Environmental Pollution, 98, 29-36. http://dx.doi.org/10.1016/S0269-7491(97)00110-3

[8] Lopez-Millan, A.-F., Sagardoy, R., Solanas, M., Abadía, A. and Abadía, J. (2009) Cadmium Toxicity in Tomato (Lycopersicon esculentum) Plants Grown in Hydroponics. Environmental and Experimental Botany, 65, 376-385. 
http://dx.doi.org/10.1016/j.envexpbot.2008.11.010

[9] Zorrig, W., Rouached, A., Shahzad, Z., Abdelly, C., Davidian, J.-C. and Berthomieu, P. (2010) Identification of Three Relationships Linking Cadmium Accumulation to Cadmium Tolerance and Zinc and Citrate Accumulation in Lettuce. Journal of Plant Physiology, 167, 1239-1247. http://dx.doi.org/10.1016/j.jplph.2010.04.012

[10] Armas, T., Pinto, A.P., de Varennes, A., Mourato, M.P., Martins, L.L., Gonçalves Simões, L.L. and Mota, A.M. (2015) Comparison of Cadmium-Induced Oxidative Stress in Brassica juncea in Soil and Hydroponic Cultures. Plant and Soil, 388, 297-305. http://dx.doi.org/10.1007/s11104-014-2330-3

[11] Monteiro, M.S., Santos, C., Soares, A.M.V.M. and Mann, R.M. (2009) Assessment of Biomarkers of Cadmium Stress in Lettuce. Ecotoxicology and Environmental Safety, 72, 811-818. http://dx.doi.org/10.1016/j.ecoenv.2008.08.002

[12] Feltrim, A.L., Filho, A.B.C., Branco, R.B.F., Barbose, J.C. and Salatiel, L.T. (2005) Yield of American Lettuce Cultivated in Soil and Hydropony during Winter and Summer Seasons, in Jaboticabal, SP. Revista Brasileira de Engenharia Agrícola e Ambiental, 9, 505-509. http://dx.doi.org/10.1590/S1415-43662005000400010

[13] Domingues, D.S., Takahashi, H.W., Camara, C.A.P. and Nixdorf, S.L. (2012) Automated System Developed to Control $\mathrm{pH}$ and Concentration of Nutrient Solution Evaluated in Hydroponic Lettuce Production. Computers and Electronics in Agriculture, 84, 53-61. http://dx.doi.org/10.1016/j.compag.2012.02.006

[14] Liu, Y., Vijer, M.G. and Peijnenburg, W.J.G.M. (2014) Impacts of Major Cations $\left(\mathrm{K}^{+}, \mathrm{Na}^{+}, \mathrm{Ca}^{2+}, \mathrm{Mg}^{2+}\right)$ and Protons on Toxicity Predictions of Nickel and Cadmium to Lettuce (Lactuca sativa L.) Using Exposure Models. Ecotoxicology, 23, 385-395. http://dx.doi.org/10.1007/s10646-014-1202-1

[15] Astolfi, S., Zuchi, S. and Passera, C. (2004) Effects of Cadmium on the Metabolic Activity of Avena sativa Plants Grown in Soil or Hydroponic Culture. Biologia Plantarium, 48, 413-418. http://dx.doi.org/10.1023/B:BIOP.0000041095.50979.b0

[16] Niu, Z.-X., Sun, L.-N., Sun, T.-H., Li, Y.-S. and Wang, H. (2007) Evaluation of Phytoextracting Cadmium and Lead by Sunflower, Ricinus, Alfalfa and Mustard in Hydroponic Culture. Journal of Environmental Sciences, 19, 961-967. http://dx.doi.org/10.1016/S1001-0742(07)60158-2

[17] Costa, E. and Leal, P.A.M. (2009) Produção de alface hidropônica em três ambientes de cultivo. Engenharia Agrícola, Jaboticaba, 29, 358-369. http://dx.doi.org/10.1590/S0100-69162009000300003

[18] Waisberg, M., Black, W.D., Waisberg, C.M. and Hale, B. (2004) The Effect of pH, Time and Dietary Source of Cadmium on the Bioaccessibility and Adsorption of Cadmium to/from Lettuce (Lactuca sativa L. cv. Ostinata). Food Chemical and Toxicology, 42, 835-842. http://dx.doi.org/10.1016/j.fct.2004.01.007

[19] Sánchez-Calderón, L., López-Bucio, J., Chacón-López, A., Gutiérrez-Ortega, A., Hernández-Abreu, E. and HerreraEstrella, L. (2006) Characterization of Low Phosphorus Insensitive Mutants Reveals a Crosstalk between Low Phosphorus-Induced Determinate Root Development and the Activation of Genes Involved in the Adaptation of Arabidopsis to Phosphorus Deficiency. Plant Physiology, 140, 879-889. www.plantphysiol.org/cgi/doi/10.1104/pp.105.073825 http://dx.doi.org/10.1104/pp.105.073825

[20] Williamson, L.C., Ribrioux, S.P.C.P., Fitter, A.H. and Leyser, H.M.O. (2001) Phosphate Availability Regulates Root System Architecture in Arabidopsis. Plant Physiology, 126, 875-882. http://dx.doi.org/10.1104/pp.126.2.875

[21] Köleli, N., Eker, S. and Cakmak, I. (2004) Effect of Zinc Fertilization on Cadmium Toxicity in Durum and Bread Wheat Grown in Zinc-Deficient Soil. Environmental Pollution, 131, 453-459. http://dx.doi.org/10.1016/j.envpol.2004.02.012

[22] Lambert, R., Grant, C. and Sauvé, S. (2007) Cadmium and Zinc in Soil Solution Extracts Following the Application of Phosphate Fertilizers. Science of the Total Environment, 378, 293-305. http://dx.doi.org/10.1016/j.scitotenv.2007.02.008

[23] Gao, X., Mohr, R.M., McLaren, D.L. and Grant, C.A. (2011) Grain Cadmium and Zinc Concentrations in Wheat as Affected by Genotypic Variation and Potassium Chloride Fertilization. Field Crops Research, 122, 95-103. http://dx.doi.org/10.1016/j.fcr.2011.03.005

[24] Rojas-Cifuentes, G.A., Johnson, B.L., Berti, M.T. and Norvell, W.A. (2012) Zinc Fertilization Effects on Seed Cadmium Accumulation in Oilseed and Grain Crops Grown on North Dakota Soils. Chilean Journal of Agricultural Research, 72, 117-124. http://dx.doi.org/10.4067/S0718-58392012000100019

[25] Gupta, D.K., Chatterjee, S., Datta, S., Veer, V. and Walther, C. (2014) Role of Phosphate Fertilizers in Heavy Metal Uptake and Detoxification of Toxic Metals. Chemosphere, 108, 134-144. http://dx.doi.org/10.1016/j.chemosphere.2014.01.030

[26] Salah, S.A. and Barrington, S.F. (2006) Effect of Soil Fertility and Transpiration Rate on Young Wheat Plants (Triticum aestivum) Cd/Zn Uptake and Yield. Agricultural Water Management, 82, 177-192. http://dx.doi.org/10.1016/j.agwat.2005.06.002 